\title{
Upaya Meminimalisir Pencemaran Sampah Di Sungai Jenes Kelurahan Laweyan Kota Surakarta
}

\author{
Anita Wijayanti ${ }^{1 *}$, Roudhotul Maksumah ${ }^{2}$, Raden Ajeng Astrie Wulandari ${ }^{3}$, \\ Fidiyawati $^{4}$, Efi Jayanti ${ }^{5}$ \\ 1,2,3,4,5 Jurusan/Program Studi Akuntansi, Fakultas Ekonomi \\ 1,2,3,4,5 Universitas Islam Batik Surakarta, Jln. KH. Agus Salim No. 10 Surakarta \\ *e-mail:itax_solo@yahoo.com
}

Informasi Artikel

Diterima Redaksi : 10 Desember 2020

Revisi Akhir : 5 Januari 2021

Diterbitkan Online : 28 Januari 2021

Kata Kunci:

Pencemaran, Sampah, Sungai, Upaya

\section{PENDAHULUAN}

Kemajuan industri dan teknologi saat ini telah membawa konsekuensi terjadinya urbanisasi yang cepat dan modernisasi pada beberapa dekade terakhir. Faktor-faktor tersebut telah mendorong pertumbuhan ekonomi dan pembangunan di perkotaan, namun demikian di sisi lain juga menyebabkan degradasi alam dan lingkungan yang mempengaruhi kualitas hidup masyarakat kota. Oleh karena itu masalah lingkungan perkotaan terkait dengan proses urbanisasi yang cepat telah menjadi bagian penting dalam pembangunan. Menurut (Purwaningrum, 2016) dengan bertambahnya jumlah penduduk maka akan mengikuti pula bertambahnya volume timbunan sampah yang dihasilkan dari aktivitas manusia.

Timbulan sampah dari hari ke hari cenderung meningkat dan bervariasi, sehingga seringkali sampah menjadi masalah akibat kurangnya pengelolaan terhadap sampah, serta terbatasnya lahan untuk Tempat Pembuangan Akhir (TPA). Cara berpikir, sikap, dan tindakan yang masih keliru terhadap sampah akan

\section{Abstrak}

Sungai Jenes yang berada di tengah kota yaitu tepatnya di Kelurahan Laweyan membuatnya rentan sekali mengalami pencemaran baik akibat sampah rumah tangga maupun sampah non rumah tangga. Dari kejadian tersebut masyarakat harus ikut andil secara langsung dalam menjaga dan merawat Sungai Jenes. Metode yang kami lakukan yakni observasi dan wawancara dengan warga Kelurahan Laweyan. Upaya yang dilakukan antara lain Sosialisasi kesadaran masyarakat kelurahan Laweyan Kota Surakarta, Penempatan tempat sampah di area tertentu, Penggolongan sampah organic dan non organic, Pemasangan jarring sampah di Sungai Jenes, Pengambilan sampah di Sungai Jenes, Evaluasi (kondisi Sungai Jenes setelah dibersihkan). Dengan adanya upaya-upaya tersebut diharapkan kondisi sungai jenes akan selalu terjaga kebersihan dan selalu terawat tanpa terjadi pencemaran lagi.

menimbulkan berbagai permasalahan yaitu sosial, lingkungan, dan kesehatan.

Permasalahan terhadap lingkungan yang diakibatkan sampah antara lain terjadinya kerusakan dalam sistem perairan, sehingga terjadi pencemaran air. Pencemaran air di wilayah di Indonesia, telah mengakibatkan terjadinya krisis air bersih. Lemahnya pengawasan pemerintah serta keengganan untuk melakukan penegakan hukum secara benar menjadikan masalah pencemaran air menjadi hal yang semakin parah.

Terjadinya pencemaran air memiliki pengaruh dalam kehidupan makhluk hidup, seperti terganggunya ekosistem air dan air bersih yang digunakan untuk memenuhi kebutuhan hidup sulit didapat. Meskipun telah ada peraturan yang melindungi kualitas air permukaaan atau sungai, limbah padat berupa sampah sering berakhir di badan air. Hal ini disebabkan karena air permukaan berada pada daerah yang rendah, sehingga segala sesuatu yang jatuh di sekitar daerah aliran sungai akhirnya bisa mencapai badan air.

Pencemaran sungai terjadi bila bila daur materi dalam lingkungan hidup mengalami 
perubahan sehingga keseimbangan dalam hal struktur maupun fungsinya terganggu. Ketidakseimbangan struktur dan fungsi daur materi terjadi karena proses alam atau juga karena perbuatan manusia (Rokhani, 2015).

Di daerah perkotaan, sampah yang berasal dari daratan sering terbawa oleh air limpasan menuju badan air. Di daerah perkotaan, secara illegal sampah sering dibuang langsung ke badan air atau dibiarkan menumpuk di bantaran sungai. Sampah kadang juga berasal dari orangorang yang beraktivitas di sekitarbantaran sungai seperti berdagang, bertani atau aktivitas lainnya. Terlepas dari sumbersumber tersebut, keberadaan sampah di badan air adalah bentuk pencemaran air. Namun demikian, materialsampah yang tak sedap dipandang dan merupakan tanda kelalaianimanusia yangimengabaikan nilainilai estetika dan ekosistem alam.

Berdasarkan latar belakang di atas, Penelitian ini bertujuan untuk memberikan gambaran pencemaran lingkungan perairan khususnya sungai yang diakibatkan oleh sampah. Penelitian ini akan membahas sumber dan jenis sampah di sungai, dampak serta upaya meminimalisir pencemaran sampah di Sungai Jenes Kelurahan Laweyan Kota Surakarta.

\section{METODE}

Dalam rangka pengabdian pada masyarakat bulan Oktober-November 2020 di Kelurahan Laweyan Kota Surakarta untuk kegiatan Upaya Meminimalisir Pencemaran Sampah di Sungai Jenes Laweyan dilaksanakan tanggal 22-25 Oktober 2020. Kegiatan ini mengggunakan metode observasi lokasi dan wawancara langsung terhadap warga sekitar lokasi Sungai Jenes dan tokoh masyarakat kelurahan Laweyan. Observasi adalah pengamatan yang dilakukan secara sengaja, sistematis mengenai fenomena social dengan gejala-gejala psikis untuk kemudian dilakukan pencatatan (Subagyo, 2004).

Sebelum kegiatan observasi dilakukan pertama telah diterima keluhan dari masyarakat pada tanggal 21 Oktober 2020 terkait sampah yang menyumbat air sungai kemudian pada tanggal 22 Oktober 2020 kami melakukan observasi sungai yang tersumbat dan di penuhi sampah.
Pada tahap kegiatan wawancara yang dilakukan kami terhadap warga sekitar Sungai Jenes maupun tokoh masyarakat Kelurahan Laweyan bertujuan untuk mengumpulkan berbagai info terkait pencemaran sungai dan penyebab tersumbatnya aliran Sungai Jenes. Tahapan ini sebagai pengambilan langkah-langkah kami selanjutnya untuk tindakan penanganan Upaya Meminimalisir Pencemaran Sampah di Sungai Jenes Kelurahan Laweyan Kota Surakarta.

Langkah-langkah tindakan penanganan Upaya Meminimalisir Pencemaran Sampah di Sungai Jenes Kelurahan Laweyan Kota Surakarta antara lain :

a) Sosialisasi kesadaran masyarakat kelurahan Laweyan Kota Surakarta

b) Penempatan tempat sampah di area tertentu

c) Penggolongan sampah organic dan non organik

d) Pemasangan jarring sampah di Sungai Jenes

e) Pengambilan sampah di Sungai Jenes

f) Evaluasi (kondisi Sungai Jenes setelah dibersihkan)

\section{HASIL DAN PEMBAHASAN}

3.1 Sosialisasi Kesadaran Masyarakat Kelurahan Laweyan Kota Surakarta

Kesadaran masyarakat kelurahan Laweyan khususnya dibantaran Sungai Jenes tentang pentingnya menjaga kelestarian dan kebersihan sungai padaumumnya cenderung rendah kepeduliannya. Hal ini diakibatkan karena masyarakat merasa tidak ketergantungan langsung pada sungai mengigat Sungai Jenes terletak ditengah kota dan di tengah kampong wisata dan industry Batik. Menurut penelitian (Ayuningtyas, 2019) tindakan pencemaran sungai disebabkan karena rendahnya kesadaran masyarakat serta tidak adanya penegakan hukum yang berlaku.

Ketika musim penghujan datang, tidak jarang sampah-sampah yang tersangkut selalu tampak dari atas sebuah jembatan di Sungai Jenes. Sampah-sampah tersebut didominasi ranting-ranting pohon, dan plastic yang tersangkut kemudian menyebabkan aliran sungai tidak mengalir dengan sempurna bahkan terhenti. Ketika 
hal itu terjadi barulah kegiatan gotong royong dan kerja bakti diselenggarakan oleh seluruh lapisan masyarakat setempat.

Mengingat kebiasaan buruk masyarakat yang tidak memiliki kepedulian terhadap kebersihan sungai maka diperlukan sosialisasi kesadaran masyarakat. Sosialisasi kesadaran masyarakat tentang pentingnya keberadaan sungai yang bersih dapat diselenggarakan dengan mengumpul kanwarga pada saat acara khusus terkait dengan menjaga lingkungan sekitar khususnya sungai ataupun diselenggarakan secara bersama-sama pada saat acara pertemuan rutin dilaksanakan seperti pertemuan rutin bapak-bapak, ibu-ibu PKK, muda-mudi Karang Taruna maupun lain sebagainya.

Pengetahuan yang dapat diberikan pada saat sosialisasi kesadaran masyarakat terkait kebersihan sungai antara lain :

a) Pentingnya peran sungai yang bersih

Sungai memengaruhi kelangsungan hidup manusia, dengan sungai yang bersih masyarakat dapat hidup dengan sehat tanpa terkena imbas dari pencemaran air di sungai.

b) Manfaat-manfaat dari Pemanfaatan sungai

Sungai tidak hanya berfungsi sebagai tempat aliran air dan pembuangan air, tetapi jika sungai bersih makam masyarakat dapat mengambil manfaat yang lebih dari itu, seperti pemanfaatan sungai menjadi tempat budidaya ikan, wisata sungai dll.

c) Akibat-akibat yang dapat terjadi ketika sungai telah tercemar

Sungai yang telah tercemar menjadi factor yang dapat memengaruhi kesehatan manusia khususnya masyarakat yang tinggal disekiar sungai tersebut. Berbagai penyakit pun dapat timbul dikarenakan pencemaran sungai.

Dengan diadakan kegiatan sosialisasi kesadaran masyarakat ini menjadi faktor pendorong untuk menambah kepedulian seluruh lapisan masyarakat terhadap kebersihan sungai.

\subsection{Pengambilan Sampah Di Sungai Setiap Minggu (Kerja Bakti)}

Pengambilan sampah secara rutin sangat penting untuk dilaksanakan untuk upaya pembersihan. Apalagi sungai Jenes merupakan sungai perbatasan kota yang rentan dengan pencemaran akibat sampah rumah tangga. Dengan dilakukan pembersihan atau pengambilan sampah secara rutin diharapkan ekosistem hayati sungai Jenes dapat terjaga terawat bersih serta aliran air menjadi lebih lancar tanpa ada sampah dan tanaman liar yang menghambat. Pengambilan sampah tidaklah harus setiap hari, keatan tersebut dapat dilakukan dengan cara kerja bakti oleh masyarakat sekitar satiap minggu sekali dan dijadikan rutinan setiap minggunya.

\subsection{Penempatan Tempat Sampah Di Area Tertentu}

Salah satu penyebab pencemaran Sungai Jenes oleh limbah sampah yaitu karena minimnya ketersediaan tempat sampah di area pemukiman warga terutama di pinggir jalan. Setiap warga yang melintasi Kampung Batik Laweyan kemungkinan dapat mencemari Sungai Jenes dengan membuang sampah sembarangan jika tidak disediakan tempat sampah di pinggir jalan. Contohnya jika turis yang berkunjung ke Kampung Batik dan jalan-jalan di sekitar area pemukiman warga pasti akan membutuhkan tempat sampah yang disediakan di pinggir jalan, jika tidak tersedia, dampaknya sampah akan dibuang ke pinggir jalan bahkan ke sungai.

Selain mencemari sungai, tanah juga dapat ikut tercemar jika masyarakat membuang sampah sembarangan. Pencemaran tanah dapat menyebabkan hilangnya keindahan alam, menimbulkan bau yang tak sedap, serta menjadi tempat tumbuh dan bersarangnya vector penyakit (Tosepu, 2016).

Oleh karena itu, diperlukan penempatan sampah di pinggir jalan terutama di setiap pos lingkungan Kelurahan Laweyan. Berdasarkan observasi, didapatkan bahwa setiap pos di lingkungan Kelurahan Laweyan belum disediakan tempat sampah. Hal ini juga dapat berguna untuk setiap warga yang sedang berada di pos dan berjaga malam akan ketersediaan tempat sampah di setiap posnya. Selain itu, setiap tempat sampah disarankan dalam penempatannya sebagai berikut:

a) Tidak mengganggu pemakai jalan (Jangan ditempatkan terlalu menengah di jalan). 
b) Di ujung gang kecil.

c) Di setiap taman, pos, dan pusat keramaian.

d) Jarak antara tempat sampah minimal $100 \mathrm{~m}$.

Karakteristik setiap tempat sampah yang disarankan yaitu sebagai berikut:

a) Bentuk: Kotak, silinder, kontainer, bin (tong), semua bertutup.

b) Sifat: Ringan, mudah dipindahkan dan mudah dikosongkan.

c) Jenis: Logam, plastik, fiberglas (GPR), kayu, bambu, rotan.

d) Pengadaan: Instansi pengelola.

\subsection{Penggolongan Sampah Organik Dan Non Organic}

Selain sampah plastik yang mencemari Sungai Jenes, juga terdapat sampah dari alam seperti batang kayu, tanaman (seperti eceng gondok), dan dedaunan. Oleh karena itu, idealnya diperlukan penggolongan pada tempat sampah organic dan non organik. Sampah organic merupakan sampah yang berasal dari makhluk baik manusia, hewan, dan tumbuhan. Contohnya seperti kertas, kayu, sisa sayuran, kulit buah, ranting pohon dan dedaunan). Sampah organik jika dibiarkan dapat membusuk karena degradasi mikroorganisme dan apabila dibuang ke perairan maka populasi mikroorganisme dapat berkembang. Berkembangnya mikroorganisme dapat menimbulkan perkembangan bakteri panthogen sehingga dapat menjadi sarang penyakit dan berbahaya bagi manusia.

Sampah non organic yaitu bukan berasal dari makhluk hidup. Jenis sampah inibiasanya dapat dikategorikan sebagai sampah yang dapat didaurulang (recycle) misalnya plastic dan logam. Adanya jenis sampah anorganik ini di perairan, maka akan terjadi peningkatan jumlah ion logam dalamaair. Sampah anorganik ini biasanya berasal dari bekas kemasan cat, minuman ringan, atau wadah lainnya yang terbuat dari logam termasuk bekas kemasan cairan kimia berbahaya, seperti pestisida. Adanya sampah anorganik akan meningkatkan kadar logam berat. Apabila ion-ion logam berasal dari logam berat maupun yang bersifat racun seperti $\mathrm{Pb}, \mathrm{Cd}$ ataupun $\mathrm{Hg}$, maka air yang mengandung ion-ion logam tersebut memiliki dampak berbahaya bagi kesehatan manusia.
Untuk mencegah berbagai dampak berbahaya tersebut yang ditimbulkan oleh pencemaran sampah, maka lebih baik sampah dipilah menjadi dua, yaitu sampah organic dan sampah non-organik. Masingmasing golongan sampah ini mempunyai tempat sendiri-sendiri. Sebagai contoh, tempat sampah berwarna kuning untuk sampah organik, hijau untuk an organik.

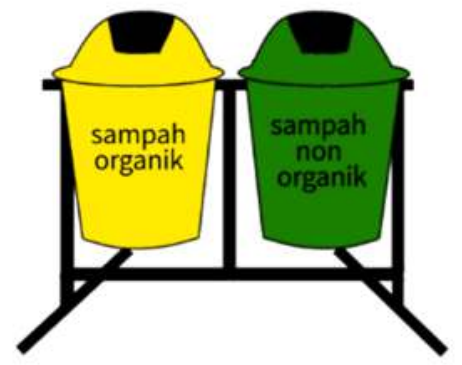

Gambar 1. Desain Tempat Sampah 50 Liter (Organik Dan Non Organik)

\subsection{Pemasangan Jaring Di Sungai Jenes}

Selain menyediakan tempat sampah, solusi yang dapat dilakukan adalah bekerja sama dengan warga setempat dengan memasang jarring untuk mencegah sampah alam maupun sampah rumahtangga yang dibuang di sungai. Apabila jarring mulai penuh, maka bias dilakukan kerjabakti bersama untuk mengambil sampah yang telah tertahan oleh jaring. Namun jika kondisi jarring sudah kurang memungkinkan untuk digunakan kembali maka sebaiknya jarring tersebut diganti dengan yang baru. Untuk menjaga kualitas jaring agar tidak cepat rusak dan berlubang, lebih baik dilakukan penggantian jarring secara temporer, misalkan diganti setiap minggu (seminggu sekali).

\subsection{Evaluasi (Kondisi Sungai Jenes Setelah Dibersihkan)}

Setelah adanya upanya pembersihan dan penataan Sungai Jenes, hal terakhir yang harus di lakukan adalah evaluasi mengenai kondisi Sungai Jenes sebelum dan sesudah di bersihkan. Evalusai di lakukan agar mempermudah pemantauan kondisi terbaru Sungai Jenes serta hal atau tindakan apa saja yang dapat dilakukann agar Sungai Jenes selalu terjaga kebersihannya dan terawat. 


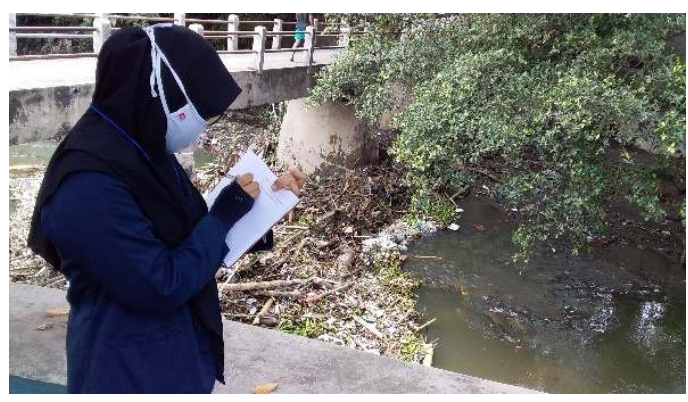

Gambar 2. Observasi Sungai Jenes

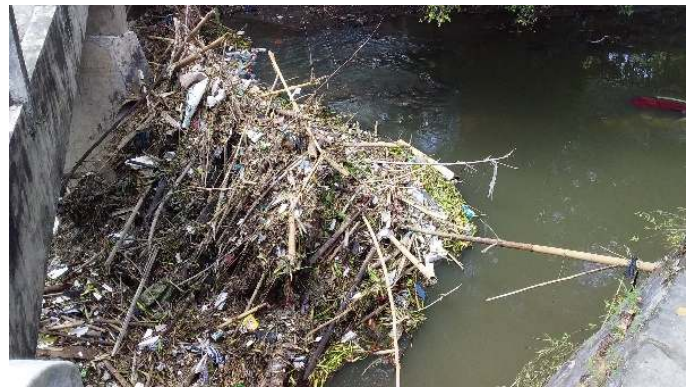

Gambar 3. Potret Sampah Yang Menumpuk Di Sungai Jenes

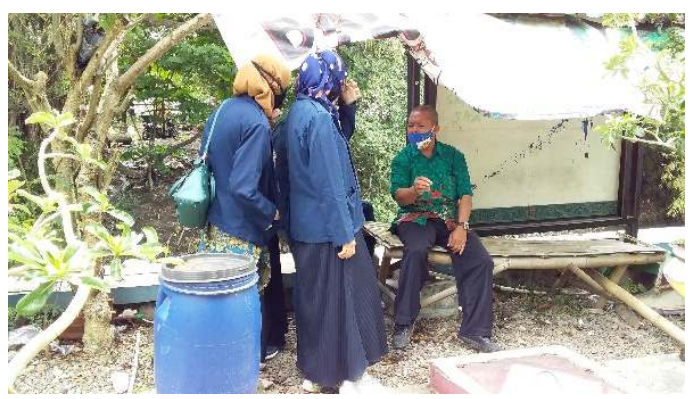

Gambar 4. Wawancara Dengan Warga Kelurahan Laweyan

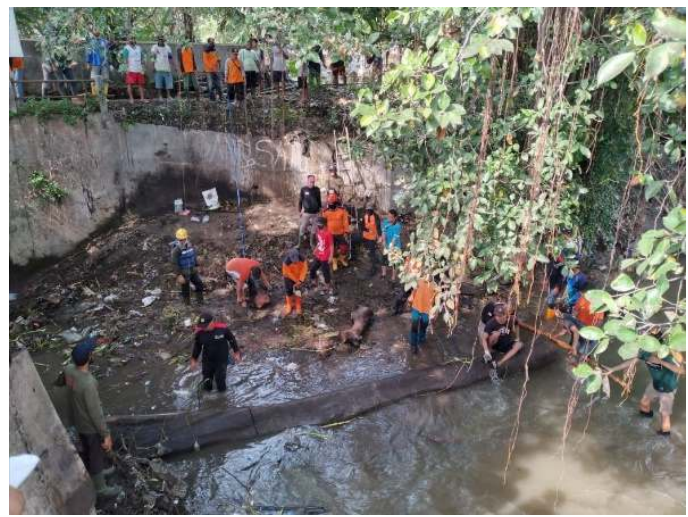

Gambar 5. Pengambilan Sampah Di Sungai Jenes (Bagian 1)

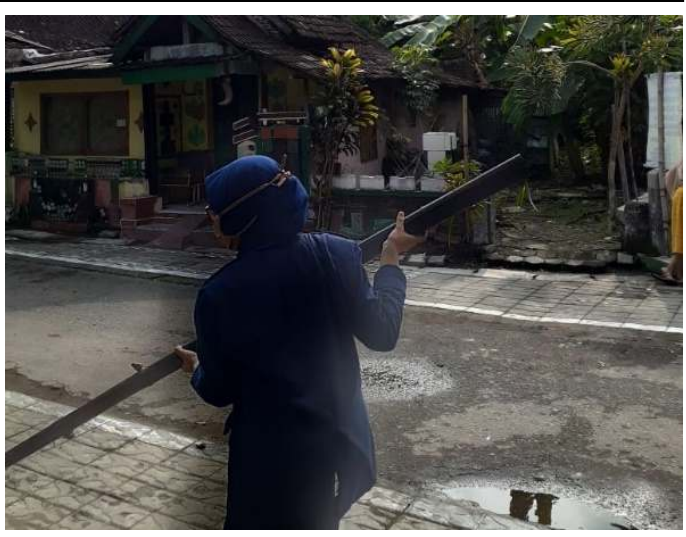

Gambar 6. Pengambilan Sampah Di Sungai Jenes (Bagian 2)

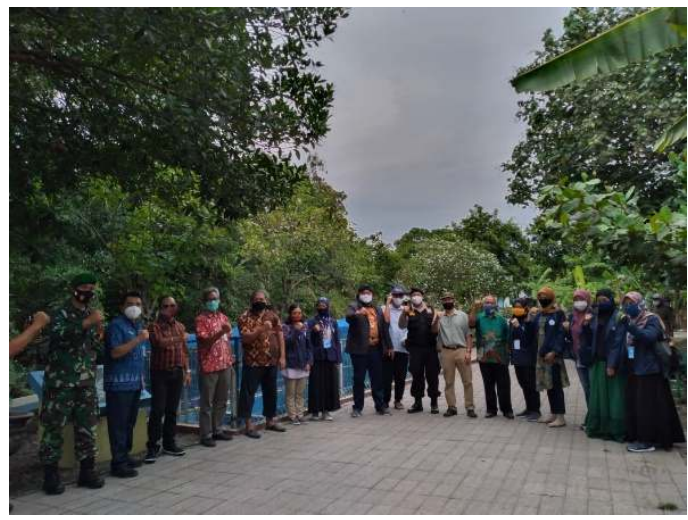

Gambar 7. Sosialisasi Sungai Jenes

\section{KESIMPULAN}

Sungai Jenes yang berada di tengah kota yaitu tepatnya di Kelurahan Laweyan membuatnya rentan sekali mengalami pencemaran baik akibat sampah rumah tangga maupun sampah non rumah tangga. Dari kejadian tersebut masyarakat harus ikut andil secara langsung dalam menjaga dan merawat Sungai Jenes. Upaya yang dilakukan antara lain Sosialisasi kesadaran masyarakat kelurahan Laweyan Kota Surakarta, Penempatan tempat sampah di area tertentu, Penggolongan sampah organic dan non organic, Pemasangan jarring sampah di Sungai Jenes, Pengambilan sampah di Sungai Jenes, Evaluasi (kondisi Sungai Jenes setelah dibersihkan).

Dengan adanya upaya-upaya tersebut diharapkan kondisi sungai jenes akan selalu terjaga kebersihan dan selalu terawat tanpa terjadi pencemaran lagi.

\section{SARAN}

Setiap pejabat Kampung Batik Laweyan diharapkan untuk dapat meningkatkan 
pengawasan terhadap masyarakat serta perlu adanya aturan desa dan sanksi yang diterapkan yang mengatur terkait larangan pembuangan sampah di sungai agar tidak terjadi pencemaran lingkungan. Selain itu, perlu adanya kerjasama dengan LPM (Lembaga Pemberdaya Masyarakat) dalam melaksanakan pelestarian lingkungan area sungai.

Bagi masyarakat yang beriman agar perlu meningkatkan kesadaran terhadap penanggulangan pencemaran lingkungan sungai dan pengelolaan sampah.

\section{UCAPAN TERIMA KASIH}

Ucapan terima kasih kami tujukan kepada Ibu Dr. Kartika Hendra Titisari.,SE, MSi, Akt, CA,CSRS,CSRA dan Ibu Anita Wijayanti, SE, AK, MM selaku Dosen Pembimbing Lapangan Kami. Ucapan terima kasih juga kami tujukan kepada warga sekitar Kelurahan Laweyan yang berpartisipasi dalam program kami. Ucapan terima kasih selanjutnya kepada temanteman mahasiswa Universitas Islam Batik Surakarta yang berupaya melaksanakan kegiatan ini.

\section{REFERENSI}

[1] P. Purwaningrum., 2016, Upaya Mengurangi Timbunan Sampah Plastik di Lingkungan, JTL, vol. 8, no. 141147.

[2] S. A. Rokhani., 2015, Pengendalian Pencemaran Lingkungan Akibat Limbah Industri Pengelolahan Mie Soun di Kecamatan Tulung Kabupaten Klaten, UAJY.

[3] J. Subagyo., 2004, Metode Penelitian Dalam Teori dan Praktek, PT Rineka Cipta, Jakarta.

[4] A. Ayuningtyas., 2019, Pencemaran Lingkungan Hidup Akibat Pembuangan Sampah Di Sungai Desa Kabupaten Tanggulangin Sidoarjo Perspektif Undang-Undang No. 32 Tahun 2009 Dan Fatwa MUI No. 47 Tahun 2014, UIN Sunan Ampel, Surabaya.

[5] R. Tosepu., 2016, Epidemiologi Lingkungan: Terori dan Aplikasi, Bumi Medika, Jakarta. 